Ida Purwami, Mimien Henie Irawati, Fatchur Rohman, Susilowati, Endang Budiasih. (2018). Program Kawasan Rumah Pangan Lestari (Krpl): Analisis Pengetahuan Lingkungan dan Sikap Peduli Lingkungan Santri Pondok Pesantren di Kecamatan Gading Kabupaten Probolinggo. Jurnal Bioeksperimen. Vol. 4 (2) Pp. 16-21. Doi: 10.23917/ bioeksperimen.v4i1.2795

\title{
Program Kawasan Rumah Pangan Lestari (KRPL): Analisis Pengetahuan Lingkungan dan Sikap Peduli Lingkungan Santri Pondok Pesantren di Kecamatan Gading Kabupaten Probolinggo
}

\author{
Ida Purwami ${ }^{1}$, Mimien Henie Irawati ${ }^{2}$, Fatchur Rohman ${ }^{2}$, Susilowati ${ }^{2}$, Endang Budiasih ${ }^{2}$ \\ Pascasarjana Pendidikan Biologi Universitas Negeri Malang \\ e-mail: iid.idapurwami@gmail.com
}

\begin{abstract}
Abstrak
Penelitian ini bertujuan untuk mendeskripsikan pengetahuan dan sikap peduli lingkungan santri terkait program Kawasan Rumah Pangan Lestari (KRPL). Penelitian dilakukan bulan November 2016 pada empat pesatren di kecamatan Gading Kabupaten probolinggo yaitu Miftahul Jannah, Miftahul Hasan, Raudatul Hasaniyah dan Mambaul Ulum. Metode yang digunakan adalah survey dengan teknik penyebaran angket kepada 129 santri. Dari hasil penelitian menunjukkan bahwa pengetahuan lingkungan santri terkait KRPL sebesar 3,3\%, dan sikap peduli lingkungan santri sebesar 28,75\% terhadap pelestarian lingkungan terkait KRPL ini. Kesimpulan dari penelitian ini adalah mayoritas santri memiliki pengetahuan dan sikap peduli lingkungan yang buruk terkait KRPL sehingga perlu ditingkatkan melalui pengembangan buku petunjuk teknis, sosialisasi dan pelatihan dengan menerapkan program KRPL di pondok pesantren Miftahul Jannah.
\end{abstract}

Kata kunci: KRPL, Pengetahuan, Sikap peduli lingkungan.

\section{Abstract}

This research aims at describing the knowledge and the caring attitude of boarding school students towards their environment due to Sustainable Reseve Food Graden Program. This paper is conducted on nopember 2016 in 4 boarding school at District Gading Probolinggo. The metode used in this research is survey by distributing the questionnaire to 129 students. The result of the study showed that the knowledge of the students toward their environment is amount 3,3\% and their caring attitude toward the environement is amount 28,75\% due to KRPL. The conclusion of the research indicates that the most of the students in the bording school acquire less knowledge and caring attitude toward KRPL. Therefore it will be needed to conduct a socialisation in order to improve students knowledge and caring attitude by implementing KRPL.

Keywords: Sustainable Reserve Food Garden program (KRPL), Knowledge, the caring attitude

\section{Pendahuluan}

Indonesia memiliki sumberdaya hayati yang sangat kaya. Menurut OECD (2013) Indonesia masuk dalam sepuluh besar produsen di dunia dalam bidang pertanian. Namun ironisnya, kebutuhan pangan penduduk Indonesia masih mengalami kerawanan pangan (Saliem et al. 2001). Pusat ketersediaan dan kerawanan pangan kementrian pertanian mencatat 100 kabupaten dari 349 kabupaten di Indonesia berpotensi mengalami rawan pangan. Oleh karena itu diperlukan upaya peningkatan ketahanan pangan (Kementrian Pertanian, 2012).

Ketahanan pangan merupakan kondisi terpenuhinya pangan bagi negara sampai dengan perseorangan yang tercermin dari tersedianya pangan yang cukup, baik jumlah maupun mutunya, aman, beragam, bergizi, merata, dan terjangkau serta tidak bertentangan dengan agama, keyakinan, dan budaya masyarakat, untuk dapat hidup sehat, aktif dan produktif secara berkelanjutan (Peraturan Menteri Pertanian nomor 15 tahun 2015). 
Memperhatikan sistem hirarki mulai dari tingkat global, nasional, regional, wilayah, rumah tangga dan individu perlu dilakukan untuk perwujudan ketahanan pangan (simatupang, 2006). Terpenuhinya kebutuhan pangan tingkat rumah tangga/ individu merupakan dasar dari terwujudnya ketahanan pangan nasional. Untuk mendukung hal tersebut pemerintah besama kementrian pertanian mencetuskan program Kawasan Rumah Pangan Lestari (KRPL), dimana KRPL merupakan upaya untuk meningkatkan ketahanan pangan dan gizi keluarga. Dengan program tersebut diharapkan terwujudnya kemandirian pangan sehingga dapat membantu prekonomian keluarga dan mewujudkan ketahanan nasional (Putri et al, 2015).

Program pemerintah yang mendukung program KRPL adalah program Ekopesantren. MoU antara Kementrian Negara Lingkungan Hidup dengan Departemen Agama Nomor : B-17/DEP.VI/LH/XII/2006 dan Nomor : DJ.II/511E/E/2006, tentang Pengembangan Peran Lembaga Pendidikan Islam dalam Pengelolaan Lingkungan Hidup. (Mangunjaya, 2013).

Peran pemerintah dalam memenuhi ketahanan pangan nasional melalui penyuluhan dan pelatihan yang diberikan langsung kepada masyarakat, dalam hal ini santri pondok pesantren Miftahul Jannah (Fediansyah dan arsiyah, 2014). Selanjutnya, santri akan dibentuk sebagai kader lingkungan yang memiliki pengetahuan untuk mensosialisasikan program KRPL. Pengetahuan terhadap lingkungan juga merupakan sarana dalam membentuk sikap peduli lingkungan (Rika, 2005). Tujuan penelitian ini untuk mendeskripsikan pengetahuan dan sikap peduli lingkungan terkait program KRPL santri pondok pesantren di Kecamatan Gading.

\section{Metode}

Jenis penelitian ini yaitu deskriptif kuantitatif yang bertujuan untuk mendapatkan informasi tentang pengetahuan dan sikap peduli lingkungan tentang Program Kawasan rumah Pangan Lestari. Responden pada penelitian ini diambil secara purposive sampling dengan metode judgment sampling yang berasal dari santri di 4 pondok pesantren yaitu Miftahul Jannah berjumlah 30 responden, Miftahul Hasan berjumlah 20 responden, Mambaul Ulum berjumlah 38 responden dan Raudatul hasaniyah berjumlah 31 responden. Teknik pengumpulan data dengan menggunakan instrumen angket dan wawancara mendalam yang diberikan kepada responden. Data hasil angket akan dianalisis secara deskriptif kuantitatif dan data wawancara akan dianalisis secara kualitatif pada penelitian ini.

\section{Hasil}

Pengetahuan lingkungan dan sikap peduli lingkungan santri pondok pesantren di kecamatan Gading secara keseluruhan masuk dalam kategori sangat rendah yaitu 3,3\% untuk pengetahuan lingkungan dan $28,75 \%$ untuk sikap peduli lingkungan. Jika hasil penelitian dirincikan berdasarkan kelompok responden, maka didapatkan hasil bahwa pada Pondok pesantren Miftahul Jannah memiliki persentase pengetahuan lingkungan 3,6\% dan sikap peduli lingkungan 40,4\%. Pondok pesantren Miftahul Hasan memiliki persentase pengetahuan lingkungan 3,8\% dan sikap peduli lingkungan 20,6\%. Pondok pesantren Mambaul Ulum memiliki persentase pengetahuan lingkungan 2,4\% dan sikap peduli lingkungan 30,8\%. Pondok pesantren Raudatul Hasaniyah memiliki persentase pengetahuan lingkungan 3,4\% dan sikap peduli lingkungan 23,2\% (gambar 1). 


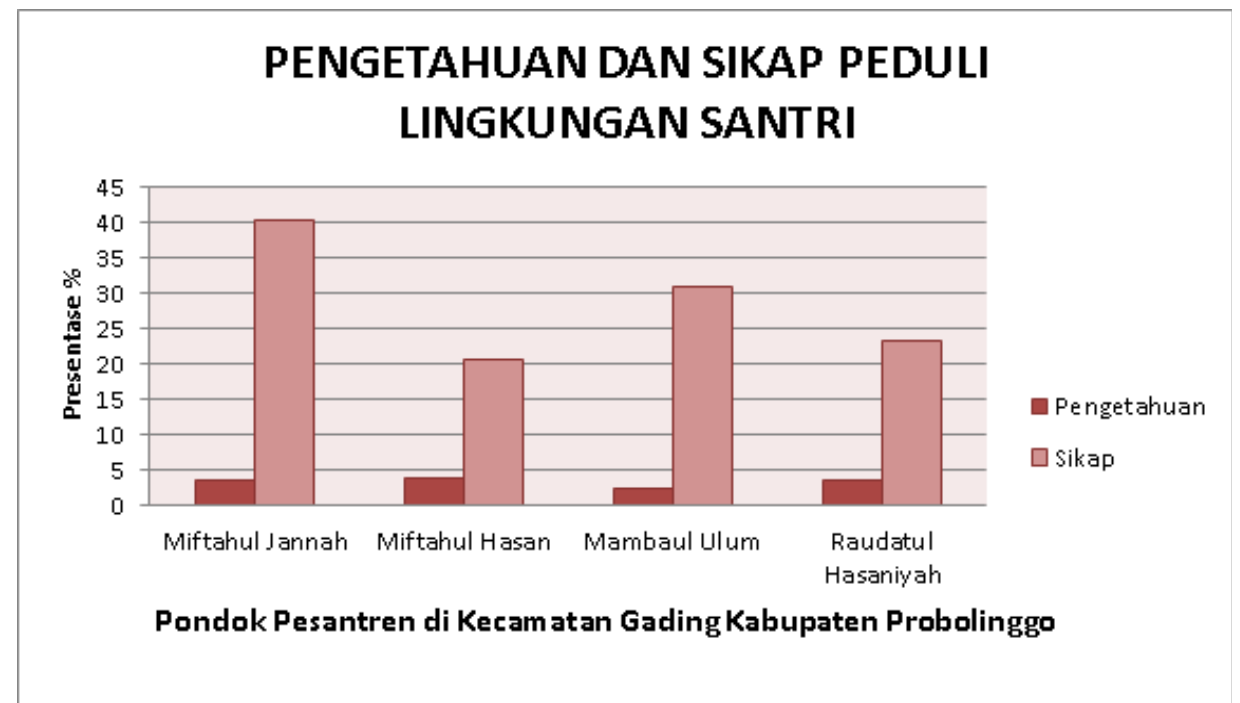

Gambar 1. Pengetahuan dan sikap peduli lingkungan santri Pondok Pesantren di Kecamatan Gading

Berdasarkan hasil presentase indikator aspek pengetahuan lingkungan pada seluruh responden Pondok pesantren jika dirincikan yaitu responden santri pondok pesantren Miftahul Jannah tentang konsep KRPL sebesar 0,8\%, indikator KRPL sebesar 1,2\%, dan pengetahuan tentang manfaat KRPL sebesar $1,6 \%$, responden santri pondok pesantren Miftahul Hasan tentang konsep KRPL sebesar 0,8\%, indikator KRPL sebesar 1,8\%, dan pengetahuan tentang manfaat KRPL sebesar 2\%, responden santri pondok pesantren Mambaul Ulum tentang konsep KRPL sebesar 0,4\%, indikator KRPL sebesar 1\%, dan pengetahuan tentang manfaat KRPL sebesar $1 \%$, responden santri pondok pesantren Raudatul Hasaniyah tentang konsep KRPL sebesar $0,8 \%$, indikator KRPL sebesar 1,2\%, dan pengetahuan tentang manfaat KRPL sebesar 1,6\% (Gambar 2).

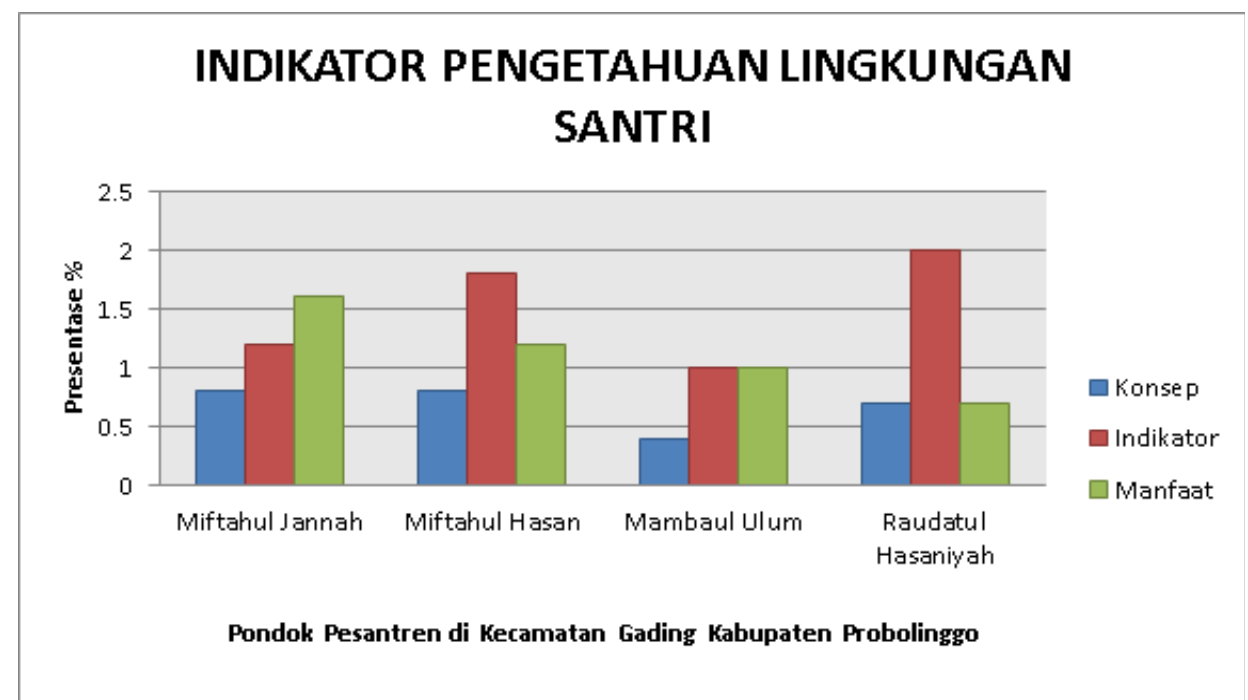

Gambar 2. Indikator Aspek Pengetahuan Lingkungan Santri Pondok Pesantren Di Kecamatan Gading. Berdasarkan hasil presentase indikator aspek sikap peduli lingkungan pada seluruh responden 
Pondok pesantren jika dirincikan yaitu responden santri pondok pesantren Miftahul Jannah tentang sikap terhadap lingkungan $14,7 \%$, pemanfaatan pekarangan $12,4 \%$, pengelolaan sampah $5,2 \%$, pola hidup sehat dan bersih 5,6\% dan konsumsi makanan seharihari $2,5 \%$, responden santri pondok pesantren Miftahul Hasan tentang tentang sikap terhadap lingkungan $5 \%$, pemanfaatan pekarangan $6,5 \%$, pengelolaan sampah $2,7 \%$, pola hidup sehat dan bersih 2,4\% dan konsumsi makanan sehari-hari 4\%, responden santri pondok pesantren Mambaul Ulum tentang tentang sikap terhadap lingkungan $10,8 \%$, pemanfaatan pekarangan $7,2 \%$, pengelolaan sampah $6 \%$, pola hidup sehat dan bersih 4,6\% dan konsumsi makanan sehari-hari 2,2\%, responden santri pondok pesantren Raudatul Hasaniyah tentang sikap terhadap lingkungan $8 \%$, pemanfaatan pekarangan $6,4 \%$, pengelolaan sampah 3,5\%, pola hidup sehat dan bersih 2,3\% dan konsumsi makanan sehari-hari 3\% (Gambar 3).

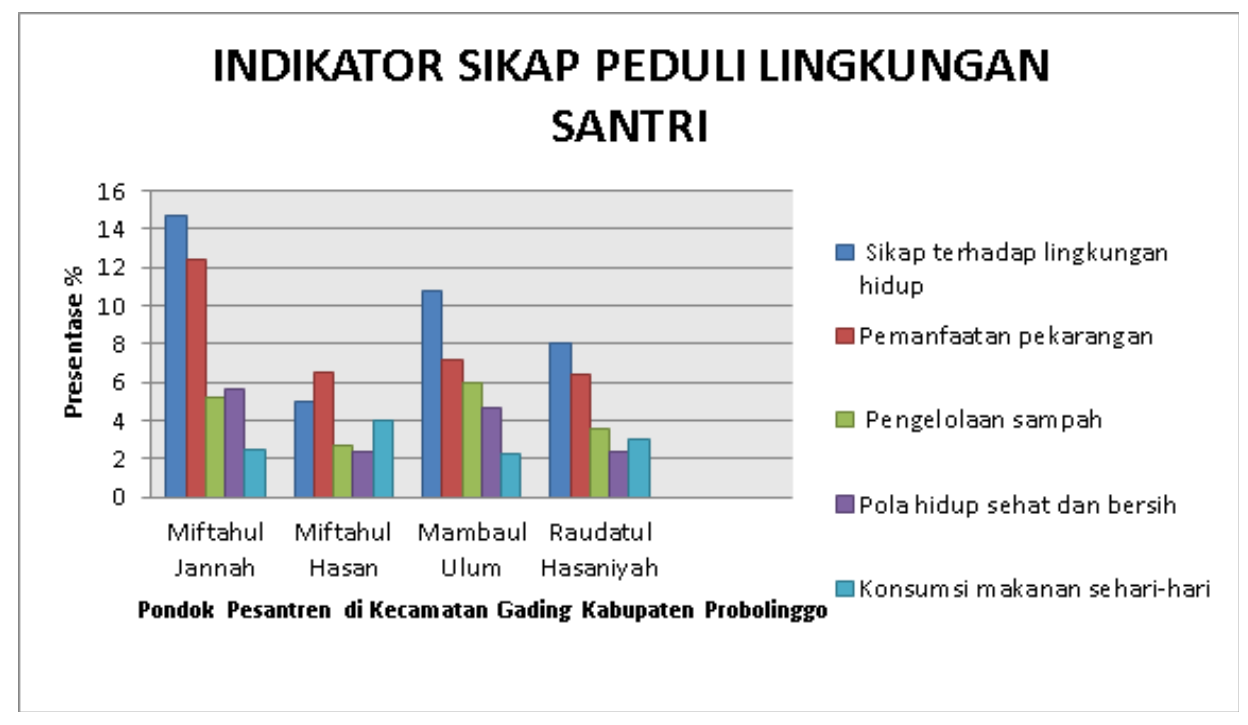

Gambar 3. Indikator Aspek Sikap Peduli Lingkungan Santri Pondok Pesantren Di Kecamatan Gading

\section{Pembahasan}

Pengetahuan lingkungan santri pondok pesantren di kecamatan Gading secara keseluruhan masuk dalam kategori sangat rendah yaitu 3,3\%, sebagaimana yang diungkapkan Arikunto (2010) yaitu kurang dari $40 \%$ dapat dikatakan sangat rendah. Hal ini dikarenakan santri pondok pesantren di Kecamatan Gading belum memiliki sumber belajar yang cukup memadai mengenai KRPL. Sumber belajar berperan sekali dalam upaya pemecahan masalah untuk mendapatkan pengetahuan (Abdullah, 2012).

Pengetahuan terkait Kawasan rumah Pangan Lestari (KRPL) merupakan hal yang harus dimiliki santri untuk bisa mengimplementasikan dalam sikap peduli lingkungan. Indikator pengetahuan KRPL meliputi pengetahuan tentang konsep KRPL, pengentahuan tentang manfaat KRPL dan pengetahuan indikator KRPL yang terdiri dari budidaya ikan organik, urban farming, pengelolahan pupuk kompos, hidroponik, veltikultur, pengelolaan sampah rumah tangga menjadi biogas. Sedangkan indikator sikap peduli lingkungan terkait KRPL meliputi sikap terhadap lingkungan hidup, pemanfaatan pekarangan, pengelolaan sampah, pola hidup sehat dan bersih serta konsumsi makanan sehari-hari (AL-Muhdar, 2015).

Sikap peduli lingkungan santri pondok pesantren di kecamatan Gading secara keseluruhan masuk dalam kategori sangat rendah yaitu $28,75 \%$. Sikap peduli lingkungan 
merupakan suatu kecenderungan seseorang yang selalu berupaya untuk mencegah kerusakan pada lingkungan alam di sekitarnya dan memiliki kemauan untuk mengembangkan upayaupaya perbaikan kerusakan alam yang terjadi (Timutisari, 2016). Hal tersebut berbanding terbalik dengan sikap santri pondok pesantren di Kecamatan Gading terhadap lingkungan sekitar contohnya santri cenderung membuang sampah secara sembarangan, menulis pohon menggunakan bolpoin atau cuter bahkan memetik tanaman secara sembarangan. Namun tanpa disengaja santri juga telah mempraktikkan sikap peduli lingkungan misalnya dalam pemanfaatan pekarangan dengan menanam secara rutin tanaman yang dibawa dari rumah selepas liburan pondok pesantren. Pemanfaatan pekarangan secara maksimal dapat membantu ketersediaan pangan rumah tangga (Adekunle, 2013). Hal ini menandakan bahwa pengetahuan santri sangat rendah. Oleh karena itu diperlukan peran pemerintah dalam penyuluhan dan pelatihan (Erdi dan arsyah, 2014) kepada santri pondok pesantren di Kecamatan Gading.

Penyuluhan dan pelatihan bermanfaat dalam membentuk kader lingkungan. Kader lingkungan mempunyai tugas yaitu sebagai promotor dan penerus program KRPL (Ferdiana, 2016). Dalam meneruskan program KRPL kader lingkungan harus mempersiapkan diri dengan sebaik-baiknya, karena keberhasilan pengembangan dan pembinaan program KRPL terletak ditangan kader lingkungan. Persiapan pelatihan kader yang kurang baik dapat mengakibatkan pandangan negatif dari pihak masyarakat (Ferdiansyah dan arsiyah, 2014).

\section{Kesimpulan dan Saran}

\section{Kesimpulan}

Pengetahuan dan sikap peduli lingkungan santri pondok pesantren di kecamatan Gading kabupaten Probolinggo terkait program Kawasan Rumah Pangan Lestari (KRPL) termasuk dalam kategori rendah. Santri pondok pesantren memiliki pengetahuan yang rata-rata sama rendahnya terkait indikator pengetahuan konsep, pengetahuan manfaat dan pengetahuan indikator. Pengetahuan santri masih rendah dikarenakan kurangnya sumber belajar dan informasi terkait program Kawasan Rumah Pangan Lestari. Sikap peduli lingkungan juga masig dalam kategori buruk/rendah . Hal ini ditandai dengan santri cenderung membuang sampah secara sembarangan, menulis pohon menggunakan bolpoin atau cuter bahkan memetik tanaman secara sembarangan. Namun secara tidak disengaja santri juga telah menerapkan praktik sikap peduli lingkungan dengan menanam pohon secara runtin setiap selepas liburan pondok pesantre.

\section{Daftar Rujukan}

Abdullah,Ramli. 2012. Pembelajaran Berbasis Pemanfaatan Sumber Belajar. Jurnal Ilmiah DIDAKTIKA Februari 2012. Vol.XII NO. 2, 216-231.

Adekunle,O.O.2013. The Role OF Home Gardens In Household Food Security in Eastern Cape: A Case Study of Three Villages in Nkonkobe Municipality. Journal of Agricultural Science. Vol.8(10):67$7610 p t$

Al Muhdhar, M.H.I. 2015.Draft Pedoman Pengembangan Kampung Organik. Laporan Penelitian tidak diterbitkan. Malang: Lembaga Penelitian Universitas Negeri Malang.

Arikunto, S. 2010. Prosedur Penelitian: Suatu Pendekatan Praktik. (Edisi Revisi). Jakarta: Rineka Cipta.

Kementrian Pertanian. Renstra Kementrian Pertanian 2015-2019.

Ferdiana, Mimien.H. I. A.M,Suhadi. 2016. Pengembangan Booklet Program Kawasan Rumah 
Pangan Lestari Dan Pengaruhnya Terhadap Pengetahuan Lingkungan Masyarakat DI Kota Malang. Jurnal Pendidikan, Vol. 1, No.7, Bln Juni, Thn 2016, Hal 1261-1264

Ferdiyansah,M.E \& Arsiyah. 2014. Peran Pemerintah Dan Kader Masyarakat Dalam Pemberdayaan Masyarakatuntuk Pengelolahan Sampah.Jurnal Administrasi Negara, Vol.2, No.2. ISSN.2338$445 X$.

Kementrian Pertanian.2012. Pengembangan Kawasan Rumah Pangan Lestari(KRPL). Jakarta: Kementrian Pertanian.

Mangunjaya, Fachruddin.2013. Ekopesantren: Bagaiamana merancang pesantren ramah lingkungan. Yayasan Pusataka obor Indonesia. Jakarta

OECD.2013. Kebijakan-kebijakan dalam bidang Pertanian: Pemantauan dan Evaluasi 2013 Negara-negara OECD dan Negara berkembang

Rika, S.S. 2015. Pengembangan Modul Pendidikan Lingkungan Hidup dengan Pendekatan Sains Lingkungan Teknologi dan Masyarakat Sebagai Upaya dalam Pengembangan Sikap Peduli Lingkungan.Tesis. Universitas Negeri Malang.

Saliem, H.P, E.M.Lokollo, M.Ariani, TB, Purwantini dan Y.Mariissa.2001. Analisis ketahanan pangan tingkat rumah tangga dan regional. Laporan penelitian Publishing sosek pertanian. Jakarta:Badan litbag pertanian. Departemen pertanian.

Simatupang, P.2006. Kebijakan dan strategi pemantapan ketahanan pangan wilayah. Balai pengkajian teknologi pertanian NTB.Universitas Mataram

Putri, N.P.A.,Aini, N.,\& Heddy,Y.B.S.2015. Evaluasi keberlanjutan Kawasan Rumah Pangan Lestari (KRPL) di Desa Girimoyo, Kecamatan Karangploso.Jurnal produksi Tanaman. Vol.3.No 4:1$4 .$.

Timutiasari. B, Mimien.H. I. A.M,Suhadi. 2016. Pembelajaran Berbasis Proyek Berbantuan Modul Program Krpl Untuk Mengembangkan Sikap Peduli Lingkungan Dan Keterampilan Proses Sains Siswa SD Islam Moh. Hatta Malang.Jurnal Pendidikan, Vol. 1, No.6, Bln Juni, Thn 2016, Hal 1185-1190 